\title{
Socio-environmental implications of process-based restoration strategies in large rivers: should we remove novel ecosystems along the Rhône (France)?
}

\author{
Maxine Thorel ${ }^{1} \cdot$ Herve Piégay $^{2} \cdot$ Carole Barthelemy $^{3} \cdot$ Bianca Räpple $^{2} \cdot$ Charles-Robin Gruel $^{2} \cdot$ Pierre Marmonier $^{4}$. \\ Thierry Winiarski ${ }^{5}$. Jean-Philippe Bedell ${ }^{5}$. Fanny Arnaud ${ }^{2} \cdot$ Gwenaelle Roux $^{6}$ • Jonh C Stella ${ }^{7}$. \\ Gabrielle Seignemartin ${ }^{2} \cdot$ Alvaro Tena-Pagan $^{2} \cdot$ Vincent Wawrzyniak $^{2,8} \cdot$ Dad Roux-Michollet $^{9} \cdot$ Benjamin Oursel $^{10}$. \\ Stéphanie Fayolle ${ }^{10} \cdot$ Céline Bertrand $^{10} \cdot$ Evelyne Franquet $^{1}$
}

Received: 17 November 2016 / Accepted: 11 March 2018

(C) Springer-Verlag GmbH Germany, part of Springer Nature 2018

\begin{abstract}
River restoration efforts require interdisciplinary approaches involving fluvial geomorphology, hydraulic engineering, ecology, sedimentology, chemistry, social geography, and sociology. We investigated the functioning of artificial structures called "Casiers Girardon" (groyne fields) in the Rhône River. We assessed potential benefits and risks linked to removing the Rhône groyne fields in a restoration context, with particular focus on the potential for increased bank erosion. Hydraulic, morphological, chemical, ecological, and social issues resulting from dismantlement were studied for terrestrialized and aquatic Casiers Girardon. Only 10\% of Casiers Girardon have maintained their aquatic features, whereas most of the Casiers are terrestrialized. Our results help to confirm the effectiveness of restoration actions; however, they also indicate uncertainties and additional knowledge needs, especially in regard to potential incompatibilities between Casier restoration and conservation. Then, an interdisciplinary conceptual model was developed to identify interventions to be considered in Casiers Girardon, according to their terrestrialization rate and physiochemical characteristics (connectivity, amount of gravel vs. fine sediment, contamination level). This model synthetizes scientific results and expert judgment and provides management recommendations based on
\end{abstract}

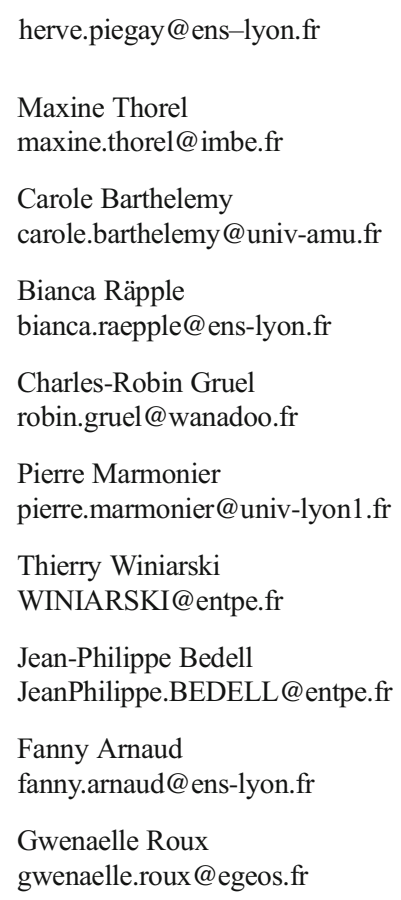

\author{
Jonh C Stella \\ stella@esf.edu \\ Gabrielle Seignemartin \\ gabrielle.seignemartin@ens-lyon.fr \\ Alvaro Tena-Pagan \\ alvaro.tena-pagan@ens-lyon.fr \\ Vincent Wawrzyniak \\ vincent.wawrzyniak@univ-fcomte.fr \\ Dad Roux-Michollet \\ dad.roux@graie.org \\ Benjamin Oursel \\ benjamin.oursel@imbe.fr \\ Stéphanie Fayolle \\ stephanie.fayolle@imbe.fr \\ Céline Bertrand \\ celine.bertrand@imbe.fr \\ Evelyne Franquet \\ evelyne.franquet@imbe.fr
}


ecological and sociological expectations about the restoration of Casiers Girardon. The model highlights high heterogeneity in functioning and ecological potential between terrestrialized and aquatic Casiers. Dismantling of terrestrialized Casiers has strong potential to provide multiple benefits, whereas aquatic Casiers could be maintained as valuable backwaters. The managing guidelines for the Casiers Girardon of the Rhône River should be adapted according to local conditions, as well as expected benefits and needs, and conducted in co-ordination with all actors involved in and affected by the restoration.

Keywords River restoration $\cdot$ Risk analysis $\cdot$ Infrastructure removal $\cdot$ Interdisciplinary assessment

\section{Introduction}

For centuries, large rivers have been the focus of engineering controls aiming at maximizing human benefits from fluvial systems. However, these modifications typically proceeded without considering their cumulative impacts or the rivers' changing natures. On most large rivers, their formerly dynamic channels were forced into a narrow corset for promoting human activities and protection. They have been heavily regulated for navigation, irrigation, flood management, and/or hydroelectricity production and modified by pollution and introduction of alien species (Besacier-Monbertrand et al. 2014). Natural dynamics and habitat heterogeneity are strongly affected by flow regulation and sediment transport disruption resulting from the implementation of dams and dikes (Ward and Stanford 1995; Besacier-Monbertrand et al. 2014). During the last decade, there has been an increasing shift towards a sustainable reconciliation of freshwater ecosystems with human societies. For example, the fields of socio-hydrology and socio-geomorphology were developed (Ashmore 2015; Blair and Buytaert 2016), partly in reaction to major flood events and the inherent difficulty of sustainably managing dynamic river systems.

The idea of "giving space to rivers" is one of the main aims in large river restoration (Opperman et al., 2009). One of the first issues was to reconnect the main channel with former side channels (e.g. Amoros and Bornette 2002; Hohensinner et al. 2004; Reckendorfer et al. 2006; Paillex et al. 2009; Van de Wolfshaar et al. 2011; Lamouroux et al. 2015). Removing engineering infrastructure (e.g., dikes, groynes, rip-rap protections) along the river should help to provide more space to the river, to reactivate bedload transport through bank erosion, and to recreate new channel and riparian habitats (Florsheim et al. 2008). However, the artificial infrastructure also induced the development of distinct habitats in the main channel and novel ecosystems (Hobbs et al. 2006; Morse et al. 2014). These waterbodies offer ecological services and could present an interesting ecological potential, by re-establishing habitat heterogeneity in regulated rivers as fish spawning, feeding, nursery, and refuge areas (Bolland et al. 2012; Clarke 2015). Moreover, artificial waterbodies support the presence of distinct communities dependent on the lentic environment. They could be considered as alternative habitats; Eick and Thiel
(2013) concluded that groyne fields are "used as alternative habitats by a high number of different fish species and life stages and could therefore contribute to sustain a speciesreach fish fauna in regulated lowland rivers."

The aim of this contribution is to explore potential benefits and risks of removing bank protection versus preserving it in its present state. Is re-erosion a win-win strategy that will both improve fluvial ecosystems and meet socio-economic expectations? It is a complex question within fluvial socio-ecosystems, requiring an interdisciplinary research approach to address the different issues. To do so, we first identified the pros and cons of such a policy, following the approach of Pont et al. (2009). We then produced scientific expertise to reduce gaps in understanding. These included improving the assessment of risks and expected benefits in terms of (i) hydraulics and morphology, (ii) potential contamination, (iii) ecology, and (iv) socio-economical issues. Next we considered the scenarios of retaining the casiers infrastructure based on retrospective diagnosis, and their removal based on prospective approaches and analog experiences. We finally proposed a conceptual model summarizing pros and cons for groyne field removal, and specific steps to consider when dismantling is planned on a given site.

Along the channel margins of the Rhône River, we find such engineering structures called "Casiers Girardon" (named for the engineer who designed these channel margins, Fig. 1), which are similar to groyne fields. Casiers Girardon were built at the end of the nineteenth century within the main channel, and they are comprised of large aquatic compartments divided by stone dikes and arranged sequentially along extensive reaches of the Rhône. Currently, a large restoration project is focused on these particular ecosystems with the primary aim of dismantling the Casiers Girardon. These features are typically novel ecosystems as illustrated by Morse et al. (2014), and they constitute a case-study in exploring the question of restoration actions from a risk-benefit perspective.

\section{The Rhône River, a "pilot" site for an ambitious restoration program}

Several factors contribute to explain why the Rhône is a pilot site to study and implement re-erosion processes following removal of bank infrastructure: (i) the history of engineering 


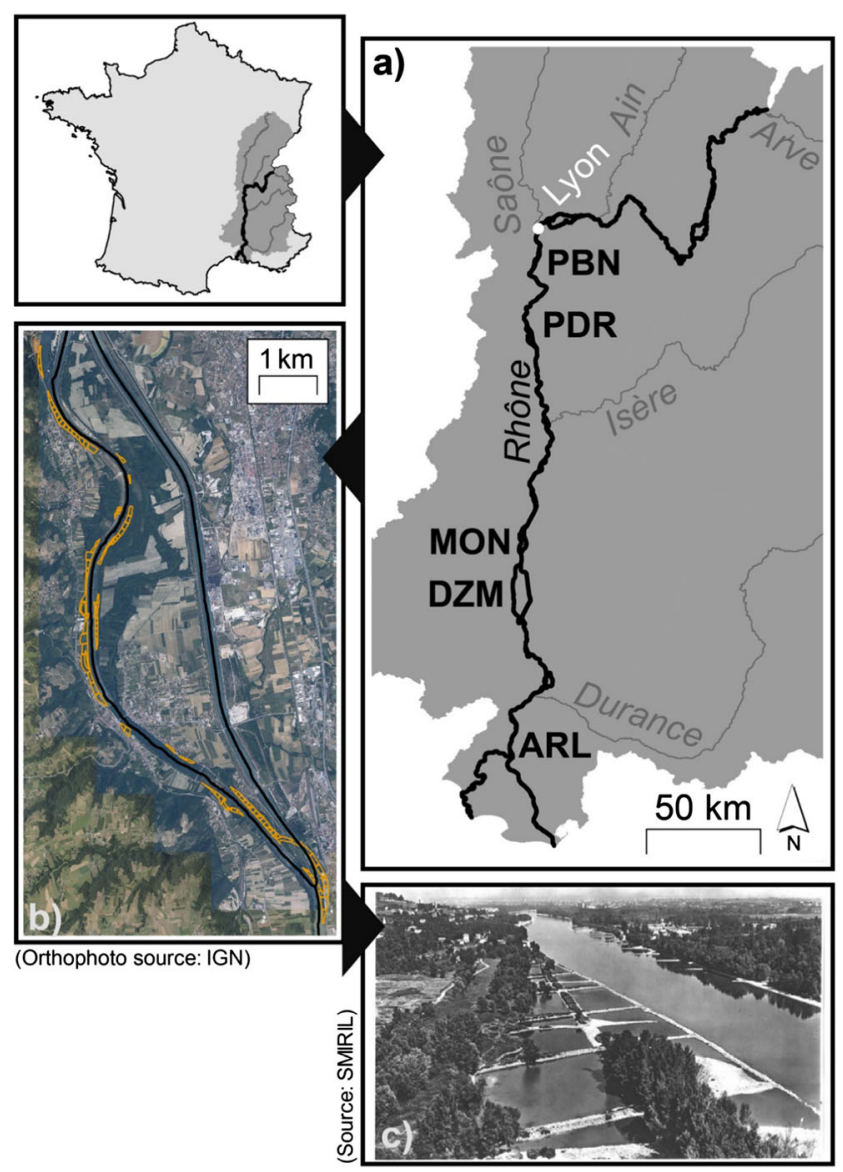

Fig. 1 a Location of the Rhône River in France and location of the 5 studied areas (PNB = Pierre-Bénite, $\mathrm{PDR}=$ Péage-de-Roussillon, $\mathrm{MON}=$ Montélimar, $\mathrm{DZM}=$ Donzère, $\mathrm{ARL}=$ Arles). $\mathbf{b}$ Overview of groyne fields in the by-passed reach of PDR. c Oblique view of some of the casiers in the downstream section of PDR early in the twentieth century before terrestrialization and afforestation

works and appearance of potentially new ecosystems of interest, (ii) a large knowledge and experience gained from previous studies about river functioning and (current and future) implications for restoration of the Rhône, which is a long adaptive process in effect since the 1990's (Table 1) and, (iii) an interdisciplinary collaboration among all the different actors (scientists, stakeholders, elected representatives, residents, and users of the Rhône) motivated by the sustainable development of the river corridor within which restoration is a critical issue.

Historically, engineering infrastructure was developed principally on the lower and middle sections of the Rhône during two main periods: (1) from the late 19th to the early twentieth century when navigation was promoted; and from the mid to late twentieth century when the production of hydroelectricity entailed a series of by-passed sections, with canals running parallel to the natural Rhône River channel. The first period, which mainly affected the 300-km-long reach downstream from Lyon to the Mediterranean Sea, involved the construction of a complex Casiers Girardon bank protection system. Longitudinal and lateral submersible infrastructures were built in the main flow channel with the aim of narrowing the natural channel and concentrating the flow by disconnecting it from secondary channels. The generally rectangular surfaces delimited by the infrastructures are referred to "Casiers Girardon" (Fig. 1.b, .c). Within a hundred years, most of these structures filled with sediment and became terrestrialized, and they no longer function in their former role as sediment traps. Proposals to remove the Casiers Girardon and restore the alluvial margins appeared after major flooding in the early 2000's (ca. 100 year return period in the lower reach). Flooding was considered as a risk by decision-makers and inhabitants, owing to channel stabilization by Casiers Girardon and associated margin sedimentation. However, over time, other ecosystem functions and services (e.g., benefits of alluvial vegetation, refuge for riparian organisms, recreation, esthetic appreciation, value of human settlement legacies...) were included in the public debate aiming to preserve Casiers Girardon. Therefore, there was a need to determine and balance the benefits and risks linked to removing the casiers. Deciding such a complex, multi-layered action necessitated a more complete understanding of riverine processes in space and time (Mika et al. 2010).

During the last decade, there has been an increasing shift towards sustainable reconciliation of freshwater ecosystems with human societies. The necessity of protecting floodplain ecosystems, and conserving or restoring ecological functions of the Rhône River has become a priority for stakeholders in the basin (Besacier-Monbertrand et al. 2014). From the beginning, this process has involved the scientific community in the debate.

The first restoration phase in the 1990's and 2000's focused on aquatic habitat restoration, principally by excavating and reconnecting secondary channels that had terrestrialized over the last century and/or increasing the minimum flows in the by-passed sections (Lamouroux et al. 2015). Numerous works focused on ecosystem conditions before, during and after restoration actions. Table 1 summarizes many of the disciplines engaged and actions taken during this initial phase.

After the 100-year flood of the Rhône River in 2003, consultations were organized in 2004 and 2005 by the French government and the individual regions. Residents and local elected representatives shared the same idea: flooding was mainly due to the riverbed filling up with sediments (Barthélémy and Souchon 2009). The riverbed narrowing due to the sedimentation of Casiers Girardon and the encroachment by vegetation was considered to be responsible for increasing the flood intensity. The Compagnie Nationale du Rhône (CNR), which manages the Rhône for navigation, hydropower, flood control, and other uses, was criticized and blamed for not properly maintaining the river - only dredging, according to the residents. The first meetings were tumultuous. Thereafter, experts in geomorphology explained the 
Table 1 Previous studies about socio-ecosystem functioning and implications on the restoration of the Rhône River

\begin{tabular}{|c|c|c|}
\hline Thema & References & Major ideas \\
\hline Ecological functioning & $\begin{array}{l}\text { Nicolas and Pont, } 1997 \text { Olivier } \\
\text { et al. } 2009 \text { Paillex et al. } 2013\end{array}$ & $\begin{array}{l}\text { Casiers Girardon provide fish habitats and improve biodiversity in artificial } \\
\text { floodplain. Major information characterizing the Rhône and its catchment } \\
\text { (climate, land use, hydrology, biodiversity, degradations pollution, } \\
\text { fragmentations, and species introductions). Restoration programs should } \\
\text { ensure an optimal functional diversity at the floodplain scale, by diversifying } \\
\text { hydraulic connections between the main channel and floodplain habitats }\end{array}$ \\
\hline Social perception & $\begin{array}{l}\text { Comby et al. } 2014 \text { Barthélémy } \\
\text { and Armani, } 2015\end{array}$ & $\begin{array}{l}\text { PCB pollution problems on the Rhône induced a socio-environmental crisis } \\
\text { which blocked restoration processes between } 2005 \text { and } 2010 \text {. A restoration } \\
\text { project can be supported by stakeholders mobilized by a local public figure, } \\
\text { and organized. Interactions between local and national levels play a major role }\end{array}$ \\
\hline Geomorphology & $\begin{array}{l}\text { Bravard } 2010 \text { Riquier et al. } 2015 \\
\text { Depret et al. } 2017\end{array}$ & $\begin{array}{l}\text { Historical change during the Holocene and the pre-modern conditions of the } \\
\text { Rhône inform trajectories for restoring selected reaches on the modern river. } \\
\text { Frequency and magnitude of hydraulic connection between the main channel } \\
\text { and floodplain modify habitat conditions in the plain and can be used to } \\
\text { design habitat restoration. Artificial abandoned channels lifespan is longer } \\
\text { than natural ones due to bedload infilling truncation. Abandoned channels } \\
\text { terrestrialization exacerbated by water level lowering and increased with } \\
\text { upstream connectivity }\end{array}$ \\
\hline Toxicology & Babut et al. 2012 Mourier et al. 2014 & $\begin{array}{l}\text { Biota-to-sediment accumulation processes provide a methodology to assess } \\
\text { contamination by PCB. PCB concentrations in sediments increase from } \\
\text { upstream to downstream stations along the Rhône }\end{array}$ \\
\hline Restoration & $\begin{array}{l}\text { Lamouroux and Olivier } 2015 \\
\text { Lamouroux et al. } 2015\end{array}$ & $\begin{array}{l}\text { Minimum flow increase induced perennial changes in fish community structure, } \\
\text { predicted by modeling. The Rhône restoration conducted to more lotic } \\
\text { environments and diverse aquatic communities and renewed social links } \\
\text { with the river }\end{array}$ \\
\hline
\end{tabular}

basics of the river's sedimentary functioning, as well as regulatory requirements. Despite restrictions on modifying the riverbed (for navigation purposes), there was an opportunity to act on the alluvial margins and more specifically on the Casiers Girardon. This approach was supported by riverside residents who were focused on sediment transport and managers whose perspectives were backed up by evaluations by river experts.

In this context, the "Plan Rhône" was established in 2009 and proposed an integrated management of the Rhône River corridor, partly funded by the European Community, and focused on sustainable development and partnership (Plan Rhône I 2009-2014 and II 2015-2020). These plans aim to bring together multiple challenges: floods, nature conservation and restoration, economic activities and uses, and recreational activities. Following the successful first phase of restoration actions that were focused on hydrological improvement and side-channel reconnection, new questions emerged concerning other factors requiring improvement. These included armored channel beds with limited mobility and bedload transport, limited hyporheic exchange, and lack of dynamism and age diversity among riparian vegetation stands.

Issues regarding the removal of Casiers Girardon are integrated into this policy framework, targeting stakeholders' participation and interdisciplinarity for flood risk management. At this stage, even though the removal of Casiers Girardon is well-supported by water stakeholders, realistic consequences of such measures are unclear. The removal of Casiers Girardon is an ambitious restoration program extending over almost $300 \mathrm{~km}$ of the river course. There are considerable uncertainties in terms of channel adjustment and ecological responses at the decadal scale, because these processes depend on bedload transport which at present only occurs occasionally during critical flood events. This program may respond to social expectations but may also have adverse socio-ecological effects. How to improve decision-making in such a complex system considering long-term adjustment is thus a critical issue. Interdisciplinary brain storming to share and confront existing knowledge, as well as to target new research efforts can be valuable in this context in order to inform and minimize uncertainties, and assess potential risks and benefits associated with such actions.

\section{Methods}

Within the Human-Environment Rhône Valley Observatory (OHM VR), scientists consider the river as a system composed of biophysical and social elements following a trajectory of adjustments linked to successive responses to 
human pressures. This requires a common conceptual framework and an interdisciplinary effort as highlighted by Pont et al. (2009). Based on this strategy, we aim to assess potential consequences and the sustainability of such an ambitious restoration policy focused on Casiers Girardon removal. What are the pros and cons of such a policy?

The OHM VR is focused on socio-ecological consequences of new riverine water policy following the exceptional floods of 2001, 2002, and 2003. Sectorial management is supposed to be replaced by a sustainable development strategy within which adaptive restoration is a critical process to improve river ecological status and reduce flood risks. The interdisciplinary research group involved in the OHM VR aims to provide new knowledge on the socio-ecosystem trajectory in considering both past conditions and present processes. This provides a basis to point out potential risks and benefits of different restoration scenarios.

The first phase of this work is based on a preliminary set of 12 interdisciplinary brain storming seminars that occurred from 2013 to 2016. Involving scientists from a large set of disciplines (sociology, social geography, political sciences, geomorphology, hydraulics, riparian and aquatic ecology, ecotoxicology, and geochemistry) and practitioners, we established a chart of potential consequences related to various scenarios. The questions asked were: What could be the consequences in river trajectory and the socio-environment if no actions were taken? Inversely, how would the river system evolve if infrastructures were removed?

In the next phase, each group of scientists developed their own methodology to validate or invalidate the hypotheses established in their field of expertise (Table 2). Groups of experts worked on five focal reaches that were potential candidates for Casiers Girardon removal (Pierre-Bénite, PBN; Péage-de-Roussillon, PDR; Montélimar, MON; Donzère, DZM; and Arles, ARL; Fig. 1.a, Table 3).

In the final phase, we built a conceptual model that would help in decision-making for rehabilitation of Casiers Girardon, considering the different contributions as well as the scientific

Table 2 Research and restoration issues about risks and gains linked to the dismantling of Casiers Girardon of the Rhône River

Research and restoration issues

- What is the contribution of Casiers Girardon to the ecological potential of Rhône River?

- How to preserve/increase biodiversity of alluvial margins?

- Consequences of restoration on contaminated sediment remobilization?

- Implications of alluvial margins restoration for residents and users of the Rhône River?

- Spatial scale for restoration (Casiers, section, site)?

- Effectiveness and sustainability of restoration actions? and contradictory debate outputs. As explained in Mika et al. (2010), "conceptual modeling is a valuable tool in refining and communicating this synthesis, both as a process and as a product." As a process it considers necessary dialog among all actors, and as a product, it considers the integration of various components, concepts, and scales for a foundational knowledge for restoration.

This model took into account the different risks and gains associated with the dismantling of the Casiers Girardon. In order to have the most complete and representative model of the system, we linked innovative scientific results acquired in our different studies on casiers, and thoughts about restoration feasibility compiled during the different meetings among actors.

\section{Results and discussion}

\section{Terrestrialized Casiers Girardon}

\section{Hydraulic and morphological issues}

Important overbank sedimentation and dewatering occurred in the casiers during the two phases of regulation due to important changes in hydraulic and roughness conditions (Fig. 2). In the 1940's, approximately 60 years after the first Girardon measures and just prior to the first by-pass projects, on average $42.9 \%$ ( $\mathrm{SD}= \pm 29.5 \%$ ) of the surface of the casiers in the bypassed reaches of PBN, PDR, MON, and DZM was terrestrial. At that time, $9.9 \%$ of these casiers were terrestrial over more than $90 \%$ of their surface area. Mean annual sedimentation rates ranged between 0.2 and $6.5 \mathrm{~cm} \mathrm{yr}^{-1}$ (mean = $3.4 \mathrm{~cm} \mathrm{yr}^{-1}, \mathrm{SD}= \pm 1.6 \mathrm{~cm} \mathrm{yr}^{-1}$ ) on pre-diversion surfaces, and between 0.2 and $10.8 \mathrm{~cm} \mathrm{yr}^{-1}$ on post-diversion surfaces (mean $=5.2 \mathrm{~cm} \mathrm{yr}^{-1}, \mathrm{SD}= \pm 2.3 \mathrm{~cm} \mathrm{yr}^{-1}$ ). Differences were large between reaches on both surfaces. The values we approximated correspond to values of sedimentation rates found in the literature for the same regional context. On the Ain, for instance, Piégay et al. (2008) found rates between 0.11 and $2.4 \mathrm{~cm} \mathrm{yr}^{-1}$. In vegetation units on the Drôme, rates ranged between 0.2 and $10.1 \mathrm{~cm} \mathrm{yr}^{-1}$ (Dufour and Piegay, 2009) and for the Ain, Doubs, and Rhône, Citterio and Piégay (2009) noted values between 0 and $2.57 \mathrm{~cm} \mathrm{yr}^{-1}$.

The removal of casier infrastructure is expected to initiate self-forming riverbank erosion that could result in new bedload supply into the channel, thus increasing diversification of grain size and associated bedforms, and vertical exchange between superficial and hyporheic flows. Riverbank erosion is also expected to enhance bar development and accretion, vegetation encroachment, and hydraulic constraints promoting new lateral erosion and vegetation rejuvenation in cyclic patterns. That would lead to a more diverse channel pattern, with new bar units, secondary channels and 
Table 3 Geographical characteristics of studied sectors Pierre-Bénite (PBN), Péage-de-Roussillon (PDR), Montélimar (MON), DonzèreMondragon (DZM) and Arles (ARL) with the status of the main channel, the kilometer point of sectors along the Rhône River from
Lyon, the sector length in kilometers $(\mathrm{km})$ and the upstream and downstream coordinates of sectors in geographical projection Lambert93 (LB93)

\begin{tabular}{llllllll}
\hline Sector & $\begin{array}{l}\text { Status of the } \\
\text { main channel }\end{array}$ & $\begin{array}{l}\text { Kilometer point (PK)(linear } \\
\text { distance in km from Lyon) }\end{array}$ & $\begin{array}{l}\text { Sector } \\
\text { length (km) }\end{array}$ & $\begin{array}{l}\text { Upstream } \\
\text { coordinates (LB93) }\end{array}$ & $\begin{array}{l}\text { Downstream } \\
\text { coordinates (LB93) }\end{array}$ \\
\hline & & & & X & Y & X & Y \\
Pierre-Bénite (PBN) & By-passed & PK3.5-PK15 & 11.45 & $843,082.98$ & $6,513,216.59$ & $840,367.07$ & $6,502,666.35$ \\
Péage-de Roussillon (PDR) & By-passed & PK50.5-PK63 & 12.66 & $837,611.81$ & $6,477,498.89$ & $841,802.25$ & $6,467,385.59$ \\
Montélimar(MON) & By-passed & PK152.5-PK166 & 14.44 & $837,573.66$ & $6,389,853.85$ & $835,039.19$ & $6,377,564.31$ \\
Donzére-Mondragon (DZM) & By-passed & PK170.5-PK200.5 & 31.04 & $834,879.41$ & $6,373,066.41$ & $836,207.23$ & $6,347,763.28$ \\
Arles (ARL) & Main channel & PK272.5-PK279.5 & 7.25 & $831,312.14$ & $6,297,737.07$ & $830,327.17$ & $6,291,140.75$ \\
\hline
\end{tabular}

backwaters, and resulting gains in habitats and biological communities cited in the following section (Rohde et al. 2005; Habersack and Piégay 2007).

However, the magnitude of these changes depends on bank material properties (i.e., proportion gravel) and the competence of the river for self-forming fluvial processes. As casiers stored overbank fine sediment over decades, we expect that they were not suitable for supplying coarse sediment to the channel. However, because the channel incised into its gravel bed once the Casiers Girardon were built and some of them initially stored gravel when hydraulic conditions were more active right after by-passing, it seems that this preliminary hypothesis is not entirely validated.

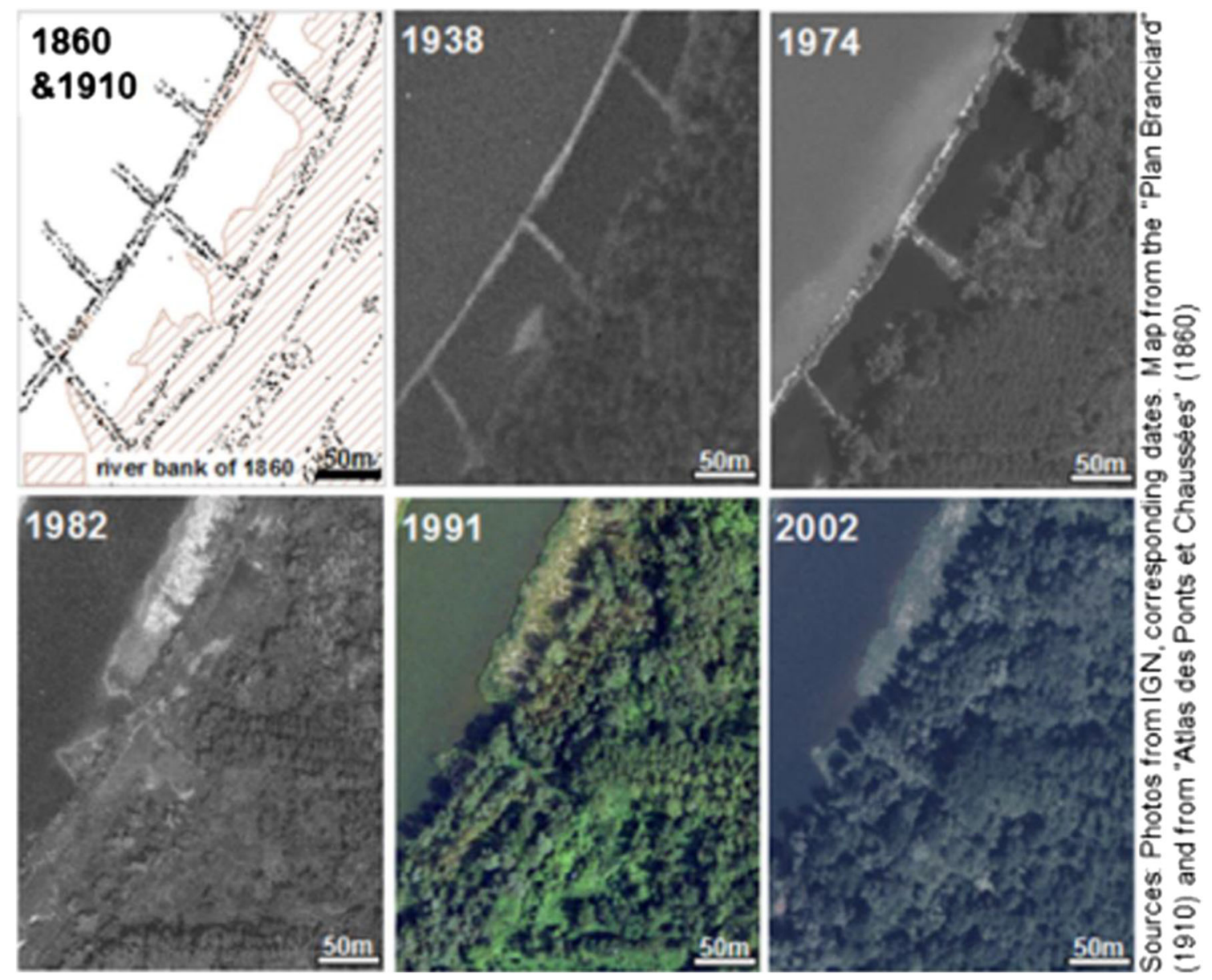

Fig. 2 Sedimentation, dewatering and vegetalization after embankment (around 1900s) and by-pass (1977) in several "Casiers Girardon" from the Rhône River at Péage-de-Roussillon (PDR; left bank, kilometer point 55) 
Estimations of gravel volumes were made on DZM and PDR by-passed reaches. We calculated the differences between the trend lines representing the ground surface and the gravel surface (to approximate the fine sediment layers), and between the gravel surface and the thalweg (to approximate the gravel layers). These estimates revealed that the coarse sediment stored in the groyne fields is considerable and more abundant than overbank fine sediment. The mean depth of fine and coarse sediment in DZM is 2.4 and $4.3 \mathrm{~m}$, respectively, while in PDR it is 1.4 and $3.2 \mathrm{~m}$. This represents volumes of fine and coarse sediment of 179 and $327 \mathrm{~m}^{3} \mathrm{~m}^{-1}$ in DZM, and 64 and $141 \mathrm{~m}^{3} \mathrm{~m}^{-1}$ in PDR. This result is, on the one hand, considered as "positive" because coarse material is potentially available in an important amount to overcome the bedload deficit and improve aquatic habitat. Conversely, it can be considered as "negative" because a lot of fine sediment could be reintroduced into the fluvial system with potentially associated contaminants.

Once infrastructure will have been removed, there is a risk of non-erosion if expected hydraulic conditions do not occur. Little feedback on experimental infrastructure removal exists on by-passed large rivers (Kloesch et al. 2011). A recent one is given on the Upper Rhine, where heavy river engineering altered the morphological and ecosystem dynamics in a similar way to the by-passed Rhône sections. A pilot site was selected to investigate sediment supply to the channel through induced bank erosion, and a physical model was built to guide the design of groyne removal (Die Moran et al. 2013). Expected sediment supply was about $6700 \mathrm{~m}^{3}$ for a $\mathrm{Q}_{10}$ flood day and $16,000 \mathrm{~m}^{3}$ for a 10 -year simulation period with a configuration implying two high, large island groynes placed further apart than the existing attached groynes. This sediment supply is, unfortunately, fairly low compared to the mean annual bedload transport capacity of the reach $(\sim$ $23,000 \mathrm{~m}^{3} \mathrm{y}^{-1}$ ), thus suggesting the placing of engineering structures into the channel. The described design was then implemented in situ. Topographic monitoring following a $\mathrm{Q}_{15}$ flood showed $1000 \mathrm{~m}^{3}$ eroded sediment, with travel distances into the channel limited to a few tens of meters (Garnier and Barillier 2015), much lower than expected by the flume experiments. Artificially adding gravel in highly active channel sections was therefore considered as an alternative for sediment supply. It has been tested in situ $\left(23,000 \mathrm{~m}^{3}\right.$ gravel augmentation in 2010; Arnaud et al. 2017) by investigating adverse morphological consequences, notably regarding (i) rapid sediment transfer and threats to downstream infrastructures and (ii) armored bed destabilization and uncontrolled bed incision. The 5-year geomorphic monitoring showed these consequences were avoided. Cost analysis of further gravel augmentations coupled with a mechanical widening of channel reaches is now being discussed in the Rhine.

If potential coarse material is available in casiers in the Rhône, as shown earlier, the debate would benefit from feedback from the Rhine hydro-sedimentary modeling, which is required to determine the suitability of specific sites for selfforming erosion because there is a probability that expected erosion may never occur. The question of sustainably widened reaches is also challenging. If bedload supply and peak flows remain at a low level, riparian vegetation might encroach on bars and recreate local geomorphic conditions similar to those observed in the embanked reaches (Habersack and Piégay 2007). Gravel augmentation sites should be promoted upstream of riverbank erosion sites to optimize local hydraulic conditions allowing bank erosion and increasing benefits from improved sediment transport and channel widening. An adaptive and opportunistic approach is required regarding gravel augmentation, re-erosion process, and channel responses to better assess the feasibility and cost-benefit effectiveness.

One issue which is not yet explored and is still difficult to assess because of little existing knowledge in terms of biophysical adjustment of rivers (e.g., vegetation encroachment) is the effect of such channel widening on water level and potential peak flow reduction downstream. These are the main expectations of local riparian owners.

\section{Contamination risks}

If casier removal and re-erosion processes are promoted, it is vital to verify that the volumes and masses of polluted sediments deposited in the casiers are below tolerable thresholds in order to target actions all along the channel.

PCB pollution problems on the Rhône River induced a socio-environmental crisis which blocked the restoration process between 2005 and 2010 (Comby et al. 2014). Exploring the level of contamination became a critical task. Results from sediment cores extracted to characterize sediment flux through time underlined a longitudinal pattern. Because of the complex and overlapping timing between pollutant flux and the construction sequence of the by-passed reaches, which influenced overbank sedimentation, pollutant depositional pattern and associated risk can be variable from one by-passed reach to another. For example, PCB pollutants affected the PDR bypassed section in the 1970's because at that time diversion favored active sedimentation while PCB flux was the highest. The peak PCB production in France occurred during the sediment filling period between 1972 and 1986. In the most contaminated casier of PDR, we observed that the sediments deposited between 1911 and 1958 exhibited very low PCB concentrations (e.g., between $0.91 \mu \mathrm{g} \mathrm{kg}^{-1} \mathrm{DW}$ and $0.63 \mu \mathrm{g} \mathrm{kg}^{-1}$ DW) whereas the sediment deposited between 1958 and 1972 showed much higher concentrations (e.g. between $60.99 \mu \mathrm{g} \mathrm{kg}^{-1} \mathrm{DW}$ and $106.33 \mu \mathrm{g} \mathrm{kg}^{-1} \mathrm{DW}$ ) with a maximum between 1972 and 1986 at the maximum PCB flux period (e.g., between $75.19 \mu \mathrm{g} \mathrm{kg}^{-1} \mathrm{DW}$ and $131.64 \mu \mathrm{g} \mathrm{kg}^{-1} \mathrm{DW}$ ). Lastly, between 1989 and 2009, the average concentration decreased to $6.48 \mu \mathrm{g} \mathrm{kg}^{-1} \mathrm{DW}$. From interpolation by 3D 
kriging of profiles coupled with coring and GPR profiling, we then estimated the mass of PCB contained in the most contaminated casier of PDR to be $1.26 \mathrm{~kg}$.

Our understanding of the Rhône River contamination underlined that contamination of casiers by PCB and trace metal elements exists, but that the space-time pattern is very variable, yet fairly well-understood. To guide bank re-erosion planning, methodological procedures have been developed to assess fine sediment contamination (e.g., potential risk) and gravel ratio (e.g., potential benefit) so that it is possible to target actions. We have seen that not all casiers are contaminated and a large part of them have stored a large amount of gravel.

\section{Habitat issues}

The terrestrialization of $90 \%$ of the groyne fields created a recent floodplain, on which woody vegetation constitutes the predominant surface cover (Fig. 2). Of the 357, casiers is covered by trees and shrubs. This area presents a limited ecological potential, except in some parts where human activities are strongly developed, and where Casiers remain the last support for alluvial vegetation that has disappeared in other places and contribute to the conservation of a green corridor network at the watershed scale. However, during consultations organized in 2004 and 2005 by the French government and the regions, residents, and local elected representatives shared the same idea: flooding was mainly due to the riverbed filling up with sediments (Barthélémy and Souchon 2009). The riverbed narrowing due to the sedimentation of Casiers and the encroachment by vegetation was considered to be responsible for increasing the flood intensity.

The current status of these forests indicates a shift from pioneer to post-pioneer communities of relatively uniform composition (Stella et al. 2015). Pre-dam surfaces show dense maturing forests with abundant shrub and vine cover, indicators of low flood disturbance frequency. On post-dam surfaces, where communities are younger, densities were lower by $30-50 \%$ compared to pre-dam surfaces. Dominant species do not differ from pre-dam surfaces. A notable feature is the near absence of regeneration of pioneer species, such as poplar (Populus spp.) or willow (Salix spp.). Instead, recruitment was dominated by box elder (Acer negundo), a shade-tolerant, post-pioneer species which is non-native and invasive in Europe. Some reaches were also dominated by regeneration of Robinia pseudoacacia, another invasive, non-native tree species.

The continuous accretion of the groyne fields in combination with the incision of the channel entails a gradual disconnection of these recent floodplains and their forests from the channel and the groundwater. This led to changes in disturbance dynamics, with no floodplain renewal processes. Over the longer term this yielded a mosaic of habitat patches of little age or compositional diversity compared to other large river systems (Stella et al. 2011, Stella et al. 2015). Young habitat patches supporting pioneer species remain unlikely to be created in the current set of conditions. With regards to woody vegetation, the deconstruction of the casiers would widen the channel, which may induce an increase in habitat diversity, for instance by the formation of gravel bars if enough sediment is provided from upstream. The deconstruction should be viewed in a reach context that encompasses cutoff channels and non-engineered river margins, as well as the casiers. This would provide a larger range of possible actions, including conservation, rehabilitation, and/or re-establishing processes which create habitats of interest and of the largest possible diversity. Partial removal and reconnection of the casiers zone should also be considered, in addition to deconstruction.

\section{Aquatic Casiers Girardon}

Only $10 \%$ of Casiers Girardon have maintained their aquatic features, and these have the characteristics of lentic ecosystems compared to the main channel. They may play a crucial habitat role for the aquatic ecosystem, including as a nursery for fish larvae, and an important source region for food. They also may serve as a refuge during natural or anthropogenic disturbances occurring in the main channel, and thus may contribute to sustain the biological diversity of the river. Moreover, aquatic systems restoration relies on social values and representations of the landscape that could be expressed in response to potential changes in the landscape (Cottet et al. 2010; Barthélémy and Armani 2015).

\section{Diversity and ecological functioning}

The $\alpha$-diversity was calculated for 12 distinct casiers at the PDR and ARL stations (Fig. 1) based on macroinvertebrates and phytoplankton diversity. The two sites presented distinct situations allowing the examination of different restoration insights. The six PDR casiers were located in a by-passed river section in contrast to the six ARL casiers, which were located directly in the main channel. Alpha diversity patterns varied among the studied casiers, ranging from 13 to 42 species for phytoplankton, and from 11 to 39 taxa for macroinvertebrates. These richness values are in the same range of values measured by Franquet et al. (1995) in a Lower Rhône River's groyne field during summer 1991. However, the diversity of remnant aquatic compartments was very heterogeneous, owing to the hydrological connectivity gradient observed between casiers and the main channel. Lateral connectivity plays an important role in the ecosystem processes and the maintenance of a diversity of habitats from lotic to lentic conditions (Ward and Stanford 1995). Highest macroinvertebrates $\alpha$-diversity was linked to intermediate levels of hydrological connectivity. These results are consistent with Tockner 
et al. (1998) in the Danube River, providing support for the Intermediate Disturbance Hypothesis (IDH, Connell 1978) where groyne fields that are partially connected are supposed to be partially disturbed by flow variability and may harbor more diverse benthic communities. With high biological diversity and important spatial variability, the Casiers Girardon could be considered as ecotones linking the main channel and the floodplain former channel lakes (Franquet et al. 1995). In contrast to macroinvertebrates, the influence of hydrologic connectivity on phytoplankton diversity appears to be limited, probably due to the phytoplankton's rapid dynamics; this suggests that the spatial pattern of phytoplankton may be controlled by more than one constraint. However, phytoplanktonic biomass, as indicated by chlorophyll $a$ (chl $a$ ) concentration, also converged to the IDH concept. High chl $a$ concentrations appeared specific to casiers with a low connectivity level with the main channel with a maximum concentration of $167.5 \mu \mathrm{g} 1^{-1}$. Then, chl $a$ concentrations decreased with increasing hydrological connectivity associated with specific ecological functioning from $53.4 \mu \mathrm{g}^{-1}$ in casiers occasionally connected to the main channel to $0.6 \mu \mathrm{g} \mathrm{l}^{-1}$ in casiers presenting a continue connection with the main channel. From our results, three types of casiers connection were determined: isolated casiers, those with an intermediary connection with the main channel, and connected casiers (Fig. 3).

Higher values of $\beta$-diversity for phytoplankton and macroinvertebrates were observed at the ARL site, with 45 species and 17 species, respectively, while the PDR site presented a higher degree of similarity for phytoplankton (37.4) and macroinvertebrates (15.4) species. Groyne fields at PDR presented a slightly lower species turn-over than at ARL. However, both sites showed a fairly high value of $\beta$-diversity ranging between 0 (complete similarity: all regional species occurred in all habitats) and 100 (complete dissimilarity, or each species occurring in a single habitat; Amoros and Bornette 2002). Finally, fauna and flora assemblages in casiers were dissimilar between PDR and ARL. This contributes to the overall diversity between the river sections. Different current velocity, substrate characteristics and hydrological connections result in a wide range of habitats and associated diverse biological assemblages when all groyne fields are considered together.

\section{Thermal considerations}

Airborne thermal infrared surveys performed during summer indicate that natural Rhône River sections exhibit fairly homogenous thermal patterns spatially. However, high temperatures can be observed locally in shallow and/or standing water areas. The Casiers Girardon are generally warmer than the river, possibly due to their disconnection from running water. The highest temperatures are observed in these aquatic features. Several casiers are colder locally, probably due to groundwater inputs. These rare environments could be potentially interesting for certain species which could use them as a thermal refuge (Fig. 3). However, these cold areas represent only a small proportion of the total aquatic habitat.

In summary, the aquatic Casiers Girardon are novel, mainly lentic ecosystems, which could be considered as ecologicallyimportant backwaters. Such features are known to provide favorable living conditions to several aquatic organisms such as amphibians or fishes during ontogeny (Tockner et al. 1998), as well as macroinvertebrates and phytoplankton as demonstrated in our study. Maintaining this infrastructure could thus enable preservation of cold casiers. Conversely, removing the infrastructure could lead to the loss of these rare habitats due to the dilution of the cold patches induced by connections with running water.

\section{Conceptual model}

We developed an interdisciplinary conceptual model to guide decision-making using innovating results summarized above, discussions during meetings among different actors, and the restoration literature (Fig. 3). This model was developed to identify interventions to be considered in Casiers Girardon of the Rhône River according to their evolution and their functioning. This model shows the complexity of restoration issue of alluvial margin of the Rhône because of a large set of potential benefits and adverse consequences. During the development of the model, it clearly appeared that management of Casiers Girardon must be distinct between terrestrialized casiers (rate of terrestrialization in casier $>90 \%$ ) and aquatic ones (rate of terrestrialization in casier $<90 \%$ ), and linked with their uses and ecological potential (Fig. 3).

Because terrestrialized casiers as they presently exist represent a limited ecological potential, dismantling them may be recommended in some cases. Preserving terrestrialized casiers was recommended in the situation of high contamination of overbank fine sediments and if the cost of removing and treating contaminated sediment was too high. Depending on the estimated remobilization of sediments during floods and the length of by-passed sections, dismantling casiers could reinitiate bank erosion and partial bedload transport. This dismantling should allow for the diversification of terrestrial and aquatic habitats, inducing new pioneer riparian communities and improving benthic and hyporheic habitats. From a sociopolitical standpoint, the restoration actions were keenly awaited by the residents and revealed a strong consensus for mitigating flood risk by means of remobilizing the alluvial margins. This, dismantling a proportion of the casiers should improve the residents' perception of the Rhône River.

Aquatic casiers, especially those with an intermediary level of hydraulic connectivity, were considered a valuable backwater habitat, as they support higher biological diversity, more extensive summer thermal refugia, and more complex ecological functioning compared to the more homogenous modified 


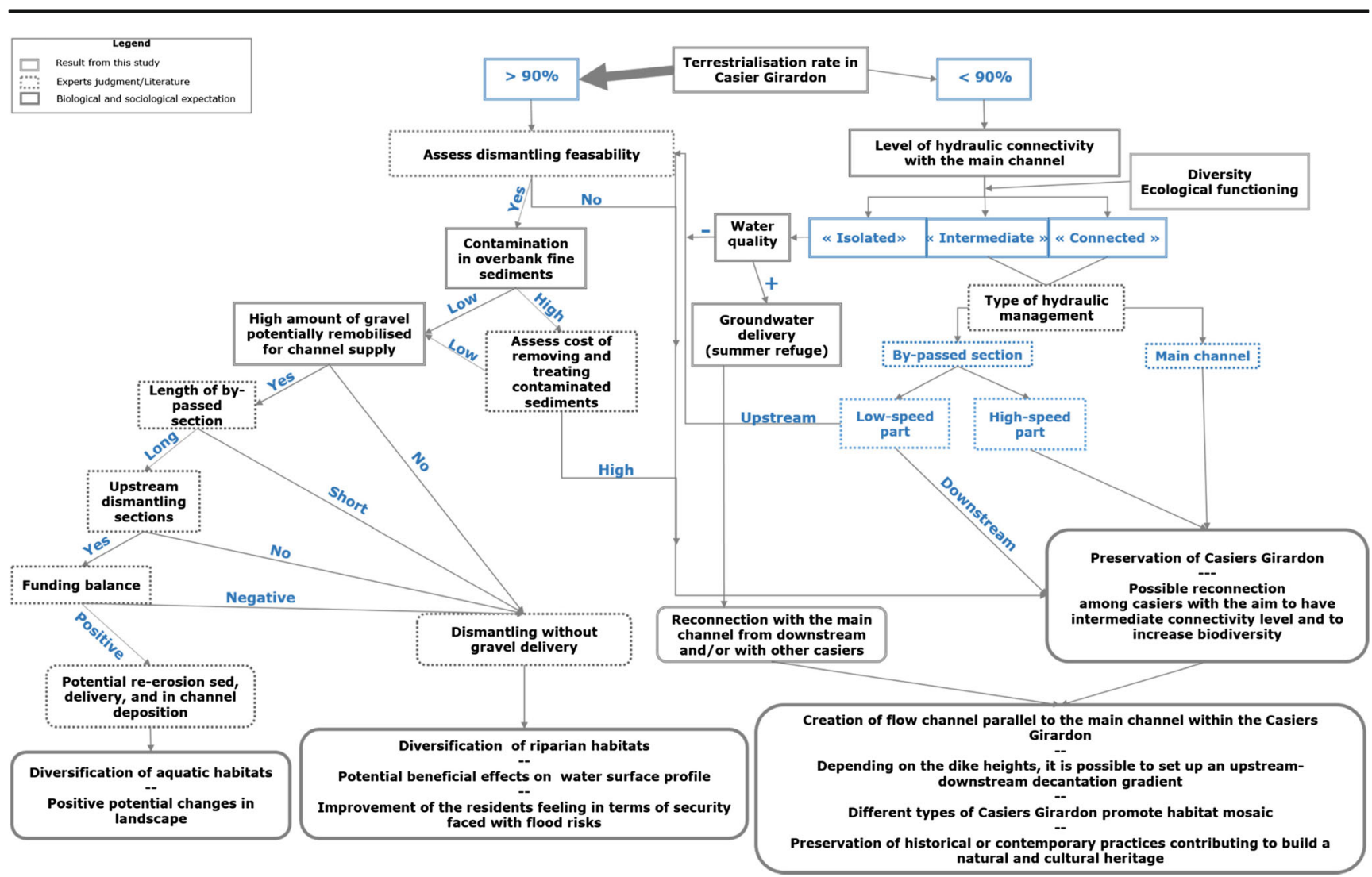

Fig. 3 The interdisciplinary conceptual model developed to identify interventions (rounded square) to be considered in Casiers Girardon according to their characters (black square) and the associated potentialities (blue text and square). This model synthetized scientific

river environment. At the scale of one sector of the river as a whole, it seems relevant to preserve the wide diversity of stillsubmerged casiers. Indeed, the aquatic casiers contribute to the current taxonomic and functional diversity of the river system.

Connectivity is not just about hydrological relationships between the main channel and the aquatic casiers, but the longitudinal connections among aquatic casiers must also be considered and studied. In cases where a set of neighboring casiers would not be dismantled, the reconnection of casiers to each other can be considered instead of a reconnection to the main channel. Such management could create a flow parallel to the main channel as an artificial secondary arm. Depending on the relative height of the dikes, a settling gradient could be established from upstream to downstream, creating a gradient of habitats. Moreover, reconnection of aquatic Casiers Girardon would allow for the preservation of historical and contemporary practices related to the natural Rhône sections which contribute to build a natural and a cultural heritage that has to be taken into account when operating on the river (Cottet 2013). Restoring aquatic systems also relies on social values and perceptions of the landscape that could be expressed in response to potential changes in land use and land cover (Cottet et al. 2010; Barthélémy and Armani results acquired during this study (double line), statements made by experts or literature (dotted line), and provided management recommendations based on ecological and sociological expectations (bold line) about Casiers Girardon restoration

2015). Currently, there is no component for these concerns in the context of the "Plan Rhône" project. Sociological knowledge has yet to be developed to link actions relating to the Casiers girardon with the point of view of residents.

Given these considerations, the conceptual model proposes four alternative trajectories for restoring the river margins of the Rhône: (i) dismantling terrestrialized casiers with large volumes of potentially mobile bedload gravel and low levels of sediment contamination, and with high potential for a diversity of aquatic habitats; (ii) dismantling terrestrialized casiers in cases where fewer benefits (gravel) and higher risk (polluted sediment) but which would increase riparian habitat diversity and decrease flood risk from the point of view of residents; (iii) reconnecting isolated aquatic casiers with appropriate water quality with other casiers and/or with the main channel at their downstream ends to create a flow channel parallel to the main channel and to promote a more heterogeneous habitat mosaic (Amoros and Bornette 2002); and (iv) Preserving aquatic casiers with an intermediate level of hydraulic connectivity with the main channel in sections with sufficient current speeds for water exchange. Designs for reconnection with the main channel and within casier fields could target intermediate levels of connectivity in order to increase biodiversity. 


\section{Conclusions}

The scientific approach outlined herein provided arguments for evaluating potential risks and benefits of removing river engineering infrastructure on the Rhône. These studies helped identify and prioritize alternative actions, but also exposed uncertainties and additional gaps in understanding. They furthermore demonstrated the complications in planning such actions, considering both restoration (e.g., removal) and conservation of casiers based on both their current properties and expected benefits. In particular, some of the aquatic features provide rare, potentially valuable habitats in a profoundly modified ecosystem, as they sustain high levels biodiversity and increase the ecological resilience of the system as a whole to perturbations.

Collectively, the studies aid in identifying which actions and which casier locations have the greatest potential benefits and the lowest risks. Evaluation of geomorphic, ecological, and contamination status have also shown that infrastructure removal is potentially a good strategy to improve the diversity of riparian ecosystems, because casiers constitute reservoirs of coarse sediment supply that can re-initiate bedload transport and associated new pioneer habitats. Contamination is potentially moderate and our knowledge of its spatio-temporal patterns has advanced, so that the risk of contaminant reintroduction owing to lateral erosion could be actively minimized.

At this stage, the debate between scientists, water managers, inhabitants, and other stakeholders is still ongoing regarding these challenging issues. More robust hydraulic studies are needed to assess potential erosion frequency and the potential amount of sediment supplied to the river channel in relation to its bedload transport capacity. Furthermore, these models will need to assess the effects of restoration actions, particularly widening of the floodway, on stage levels both at low and peak flows. There is still a need to explicitly consider potential responses in terms of flood risk benefits (i.e., there are no explicit feedbacks identified yet on the potential effects of such a strategy), and of monitoring to assess actual ecological responses (e.g., channel adjustments to infrastructure removal).

Even with a fairly wide social consensus, we should expect potential conflicts due to fears related to landscape changes (e.g., perception by locals of an increased flood risk due to bar development and riparian vegetation encroachment following channel widening) or disappointments because ecological responses could be less marked than expected. These may include lower-than-expected rates of long-term channel widening, sediment remobilization, active bedload transport, channel and riparian habitat creation, and few sustained solutions because of gaps in our understanding of the restoration processes and trajectories. Can we expect re-initiation of bank erosion to be effective enough to improve channel and riparian habitats or should it be combined with artificial sediment reintroduction (e.g., as recommended downstream of the Kembs dam on the Rhine)? How should we communicate with river basin inhabitants to better inform them of potential solutions, potential risks, and the range of responses possible with restoration actions?

Novel ecosystems resulting from human actions can have potentially benefits, and a risk-analysis approach is a critical method for defining objectives and target actions in river management. River restoration is a multi-faceted process that should simultaneously consider ecological conservation, risk mitigation, maintenance of natural processes and ecosystem services, and multi-beneficiary satisfaction in an integrated and sustainable perspective.

Acknowledgements The authors thank Agence de l'Eau RhôneMéditerrannée \& Corse and Compagnie Nationale du Rhône (CNR) for their financial support and collaboration. We also thank Groupe de Recherche Rhône Alpes sur les Infrastructures et l'Eau (GRAIE) and Zone Atelier Bassin du Rhône (ZABR), and in particular, Anne Clemens. Thanks to Antonin Vienney, Lucille Priour, Patrick Modrak, Oriane Villet and Cécile Claret for their support on field work and sample analysis.

Funding information This work was funded by the Labex DRIIHM, French programme "Investissements d'Avenir" (ANR-11-LABX-0010) which is managed by the ANR, within the Observatoire HommesMilieux Vallée du Rhône (OHM VR).

\section{References}

Amoros C, Bornette G (2002) Connectivity and biocomplexity in waterbodies of riverine floodplains. Freshw Biol 47:761-776. https://doi.org/10.1046/j.1365-2427.2002.00905.x

Arnaud F, Piégay H, Béal D, Collery P, Rollet AJ (2017) Monitoring gravel augmentation in a large regulated river and implications for process-based restoration. Earth Surf Process Landf 42:2147-2166. https://doi.org/10.1002/esp.4161

Ashmore P (2015) Towards a sociogeomorphology of rivers. Geomorphology 251:149-156. https://doi.org/10.1016/j.geomorph. 2015.02.020

Babut M, Lopes C, Pradelle S, Persat H, Badot PM (2012) BSAFs for freshwater fish and derivation of a sediment quality guideline for PCBs in the Rhone basin, France. J. Soil Sediments 12:241-251. https://doi.org/10.1007/s11368-011-0448-y

Barthélémy C, Souchon Y (2009) La restauration écologique du Rhône sous le double regard du sociologue et de l'écologue. Natures Sci Sociétés 17:113-121. https://doi.org/10.1051/nss/2009025

Barthélémy C, Armani G (2015) A comparison of social processes at three sites of the French Rhone River subjected to ecological restoration. Freshw Biol 60:1208-1220. https://doi.org/10.1111/fwb. 12531

Besacier-Monbertrand AL, Paillex A, Castella E (2014) Short-term impacts of lateral hydrological connectivity restoration on aquatic macroinvertebrates. Riv Res Appl 30:557-570. https://doi.org/10.1002/ rra. 2597

Blair P, Buytaert W (2016) Socio-hydrological modelling: a review asking "why, what and how?". Hydrol Earth Syst Sci 20:443-478. https://doi.org/10.5194/hess-20-443-2016

Bolland JD, Nunn AD, Lucas MC, Cowx IG (2012) The importance of variable lateral connectivity between artificial floodplain 
waterbodies and river channels. Riv Res Appl 28:1189-1199. https://doi.org/10.1002/rra.1498

Bravard JP (2010) Discontinuities in braided patterns: the River Rhône from Geneva to the Camargue delta before river training. Geomophology 117:219-233. https://doi.org/10.1016/j.geomorph. 2009.01.020

Citterio A, Piégay H (2009) Overbank sedimentation rates in former channel lakes: characterization and control factors. Sedimentology 56:461-482. https://doi.org/10.1111/j.1365-3091.2008.00979.x

Clarke SJ (2015) Conserving freshwater biodiversity: the value, status and management of high quality ditch systems. J Nat Cons 24:93100. https://doi.org/10.1016/j.jnc.2014.10.003

Comby E, Le Lay YF, Piegay H (2014) How chemical pollution becomes a social problem. Risk communication and assessment through regional newspapers during the management of PCB pollutions of the Rhone River (France). Sci The Total Environ 482:100-115. https:// doi.org/10.1016/j.scitotenv2014.02.137

Connell JH (1978) Diversity in tropical rainforests and coral reefs. Science 199:1302-1310

Cottet M, Rivière-Honegger A, Piégay H (2010) Mieux comprendre la perception des paysages de bras morts en vue d'une restauration écologique : quels sont les liens entre les qualités esthétique et écologique perçues par les acteurs? Norois 216:85-103. http:// norois.revues.org $/ 3408$

Cottet M. (2013) Caractériser les valeurs environnementales au cours du temps : une étape indispensable à la gestion des patrimoines naturels : Le cas de la restauration des bras morts de l'Ain et du Rhône, VertigO - la revue électronique en sciences de l'environnement. http:// vertigo.revues.org/13558. Accessed 30 May 2013

Depret T, Riquier J, Piégay H (2017) Evolution of abandoned channels : insights on controlling factors in a multi-pressure river systems. Geomorpholy 294:99-118. https://doi.org/10.1016/j.geomorph. 2017.01.036

Die Moran A, El Kadi AK, Mosselman E, Habersack H, Lebert F, Aelbrecht D, Laperrousaz E (2013) Physical model experiments for sediment supply to the old Rhine through induced bank erosion. Internat J Sed Res 28:431-447. https://doi.org/10.1016/S10016279(14)60003-2

Dufour S, Piegay H (2009) From the myth of a lost paradise to targeted river restoration: forget natural references and focus on human benefits. Riv Res Appl 25:568-581. https://doi.org/10.1002/rra.1239

Eick D, Thiel R (2013) Key environmental variables affecting the ichthyofaunal composition of groyne fields in the middle Elbe River, Germany. Limnologica 43:297-307. https://doi.org/10.1016/j. limno.2013.01.001

Florsheim JL, Mount JF, Chin A (2008) Bank erosion as a desirable attribute of rivers. Bioscience 58:519-529. https://doi.org/10.1641/ b580608

Franquet E, Cellot B, Pont D, Bournaud M (1995) Environmental and macroinvertebrate dynamics in the lower rhone river and a lateral dike field - a study matching 2 functioning descriptors. Hydrobiologia 308:207-217. https://doi.org/10.1007/bf00006872

Garnier A, Barillier A (2015) The Kembs project: environmental integration of a large existing hydropower scheme. La Houille Blanche 4: 21-28. https://doi.org/10.1051//hb/20150041

Habersack H, Piégay H (2007) 27 River restoration in the Alps and their surroundings: past experience and future challenges. In: Rinaldi M, Habersack H, Piégay H (ed) Gravel Bed Rivers VI: From Process Understanding to the Restoration of Mountain Rivers 11: 703-735

Hobbs RJ, Arico S, Aronson J, Baron JS, Bridgewater P, Cramer VA, Epstein PR, Ewel JJ, Klink CA, Lugo AE, Norton D, Ojima D, Richardson DM, Sanderson EW, Valladares F, Vila M, Zamora R, Zobel M (2006) Novel ecosystems: theoretical and management aspects of the new ecological world order. Glob Ecol Biogeogr 15: 1-7. https://doi.org/10.1111/j.1466-822x.2006.00212.x
Hohensinner S, Habersack H, Jungwirth M, Zauner G (2004) Reconstruction of the characteristics of a natural alluvial riverfloodplain system and hydromorphological changes following human modifications: the Danube River (1812-1991). Riv Res Appl 20:25-41

Kloesch M, Liedermann M, Habersack H (2011) Riverbank erosion processes within a major bank restoration project. In: Habersack $\mathrm{H}$, Schober B, Walling D (ed) International conference on the status and future of the world's large rivers, april 11-14, 2011, Vienna, Austria, Abstract Book, 287

Lamouroux N, Gore JA, Lepori F, Statzner B (2015) The ecological restoration of large rivers needs science-based, predictive tools meeting public expectations: an overview of the Rhone project. Freshw Biol 60:1069-1084. https://doi.org/10.1111/fwb.12553

Lamouroux N, Olivier JM (2015) Testing predictions of changes in fish abundance and community structure after flow restoration in four reaches of a large river (French Rhône). Freshw Biol 60:1118-1130. https://doi.org/10.1111/fwb.12324

Mika S, Hoyle J, Kyle G, Howell T, Wolfenden B, Ryder D, Keating D, Boulton A, Brierley G, Brooks AP, Fryirs K, Leishman M, Sanders M, Arthington A, Creese R, Dahm M, Miller C, Pusey B, Spink A (2010) Inside the "Black Box" of river restoration: using catchment history to identify disturbance and response mechanisms to set targets for process-based restoration. Ecol Soc 15(4):8

Morse NB, Pellissier PA, Cianciola EN, Brereton RL, Sullivan MM, Shonka NK, Wheeler TB, McDowell WH (2014) Novel ecosystems in the Anthropocene: a revision of the novel ecosystem concept for pragmatic applications. Ecol Soc 19:12. https://doi.org/10.5751/es06192-190212

Mourier B, Desmet M, Van Metre PC, Mahler BJ, Perrodin Y, Roux G, Bedell JP, Lefèvre I, Babut M (2014) Historical records, sources, and spatial trends of PCBs along the Rhône River (France) Sci Total Environ 476-477:568-576. doi.https://doi.org/10.1016/j.scitotenv. 2014.01.026

Nicolas Y, Pont D (1997) Hydrosedimentary classification of natural and engineered backwaters of a large river, the lower Rhône: possible applications for the maintenance of high fish biodiversity. River Res Appl 13:417-431. https://doi.org/10.1002/(SICI)10991646(199709/10)13:5<417::AID-RRR466>3.0.CO;2-E

Olivier JM, Dole-Olivier MJ, Amoros C, Carrel G, Malard F, Lamouroux N, Bravard JP (2009) Introduction to European rivers. In: Tockner $\mathrm{K}$, Robinson CT, Uehlinger A (ed) Rivers of Europe, $1^{\text {st }}$ edn, Academic Press, London, pp 1-22

Opperman JJ, Galloway GE, Fargione J, Mount JF, Richter BD, Secchi S (2009) Sustainable floodplains through large-scale reconnection to rivers. Science 326:1487-1488. https://doi.org/10.1126/science. 1178256

Paillex A, Doledec S, Castella E, Merigoux S (2009) Large river floodplain restoration: predicting species richness and trait responses to the restoration of hydrological connectivity. J Appl Ecol 46:250 258. https://doi.org/10.1111/j.1365-2664.2008.01593.x

Paillex A, Dolédec S, Castella E, Mérigoux S, Aldridge DC (2013) Functional diversity in a large river floodplain: anticipating the response of native and alien macroinvertebrates to the restoration of hydrological connectivity. J Appl Ecol 50:97-106. https://doi.org/ 10.1111/1365-2664.12018

Piégay H, Hupp CR, Citterio A, Dufour S, Moulin B, Walling DE (2008) Spatial and temporal variability in sedimentation rates associated with cutoff channel infill deposits: Ain River, France. Water Resour Res 44:5. https://doi.org/10.1029/2006WR005260

Pont D, Piegay H, Farinetti A, Allain S, Landon N, Liebault F, Dumont B, Richard-Mazet A (2009) Conceptual framework and interdisciplinary approach for the sustainable management of gravel-bed rivers: the case of the Drôme River basin (SE France). Aq Sci 71:356-370. https://doi.org/10.1007/s00027-009-9201-7 
Reckendorfer W, Baranyi C, Funk A, Schiemer F (2006) Floodplain restoration by reinforcing hydrological connectivity: expected effects on aquatic mollusc communities. J Appl Ecol 43:474-484. https://doi.org/10.1111/j.1365-2664.2006.01155.x

Riquier J, Piégay H, Šulc Michalková M (2015) Hydromorphological conditions in eighteen restored floodplain channels of a large river : linking patterns to processes. Freshw Biol 60:1085-1103. https:// doi.org/10.1111/fwb.12411

Rohde S, Schütz M, Kienast F, Englmaier P (2005) River widening: an approach to restoring riparian habitats and plant species. River Res Appl 21:1075-1094. https://doi.org/10.1002/rra.870

Stella JC, Hayden MK, Battles JJ, Piégay H, Dufour S, Fremier AK (2011) The role of abandoned channels as refugia for sustaining pioneer riparian forest ecosystems. Ecosystems 14:776-790. https://doi.org/10.1007/s10021-011-9446-6

Stella JC, Piégay H, Riddle JD, Gruel C, Räpple B (2015) Riparian forest impacts and dynamics on large rivers managed for multiple uses; insights from the Sacramento (California, USA) and Rhône (France). Proceedings of the Second Integrative Sciences and Sustainable Development of Rivers (IS Rivers) Conference, Lyon, France, 22-26 June 2015.

Tockner K, Schiemer F, Ward JW (1998) Conservation by restoration: the management concept for a river-floodplain system on the Danube River in Austria. Aquatic Conserv: Mar Freshw Ecosyst 8:71-86

Van de Wolfshaar KE, Middelkoop H, Addink E, Winter HV, Nagelkerke LAJ (2011) Linking flow regime, floodplain lake connectivity and fish catch in a large river-floodplain system, the Volga-Akhtuba floodplain (Russian Federation). Ecosystems 14:920-934. https:// doi.org/10.1007/s10021-011-9457-3

Ward JV, Stanford JA (1995) Ecological connectivity in alluvial river ecosystems and its disruption by flow regulation. Reg River 11: 105-119. https://doi.org/10.1002/rrr.3450110109

\section{Affiliations}

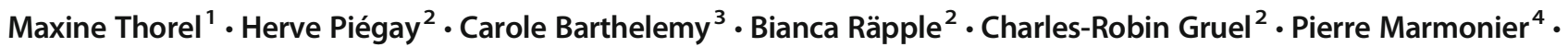
Thierry Winiarski ${ }^{5} \cdot$ Jean-Philippe Bedell ${ }^{5} \cdot$ Fanny Arnaud $^{2} \cdot$ Gwenaelle Roux $^{6} \cdot$ Jonh C Stella ${ }^{7}$. Gabrielle Seignemartin ${ }^{2} \cdot$ Alvaro Tena-Pagan $^{2} \cdot$ Vincent Wawrzyniak $^{2,8} \cdot$ Dad Roux-Michollet $^{9} \cdot$ Benjamin Oursel $^{10}$. Stéphanie Fayolle ${ }^{10} \cdot$ Céline Bertrand $^{10} \cdot$ Evelyne Franquet $^{1}$

Herve Piégay

herve.piegay@ens-lyon.fr

1 Mediterranean Institute for Biodiversity and Ecology (IMBE), Aix Marseille Univ, CNRS, IRD, Avignon Univ, Campus Étoile Faculté des Sciences St-Jérôme Case 421 Av Escadrille Normandie Niémen, 13397 Marseille Cedex 20, France

2 UMR 5600 CNRS EVS, Univ. of Lyon, ENS of Lyon, 15 Parvis R. Descartes, F-69362 Lyon, France

3 IRD, LPED, Aix Marseille Univ, Marseille, France

4 UMR-CNRS 5023 Laboratoire d'Ecologie des Hydrosystèmes Naturels et Anthropisés (LEHNA), University Claude Bernard Lyon 1, 43 Boulevard du 11 Novembre 1918, 69622 Villeurbanne, Cedex, France
5 UMR 5023 LEHNA, ENTPE, Univ. of Lyon, 2 Rue Maurice Audin, F-69518 Vaulx-en-Velin, France

6 éGéos SASU, 6 rue Bordeau, 69001 Lyon, France

7 State University of New York College of Environmental Science and Forestry (SUNY-ESF), One Forestry Drive, Syracuse, NY 13210, USA

8 ThéMA, CNRS, Université Bourgogne Franche-Comté, 32 Rue Mégevand, F25030 Besançon Cedex, France

9 GRAIE, Campus LyonTech la Doua, 66 Boulevard Niels Bohr, CS 52132, 69603 Villeurbanne Cedex, France

10 CNRS, IRD, IMBE, Aix Marseille Univ, Univ Avignon, Marseille, France 